\title{
Effective Media Use: Using Film And Television To Instruct An Organizational Behavior Course
}

Tom Kernodle, Touro University International and Berkeley College, USA

\begin{abstract}
Media can be used to effectively teach Organizational Behavior $(O B)$ concepts at the college level. University instructors have the option to employ several different methods of teaching in order to convey course concepts in the classroom. This article describes the effectiveness that five particular pieces of media can have on active learning in an undergraduate OB class. The films For Love of the Game, 300, and 12 Angry Men, as well as the episode All Due Respect of the television series The Sopranos and the episode Did I Stutter? of the television series The Office, will be analyzed. This article provides a background on each piece of media, as well practical suggestions on how to use them to instruct $O B$.
\end{abstract}

Keywords: Organizational Behavior, Management Education, Media Use

\section{INTRODUCTION}

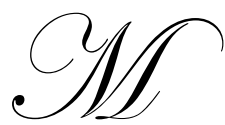

edia can be used to effectively teach Organizational Behavior (OB) concepts at the college level. University instructors have the option to employ several different methods of teaching in order to convey course concepts in the classroom. Various methods of pedagogy can be used to instruct OB courses, such as review and discussion questions, point-counterpoint debates, individual and group exercises, ethical dilemma exercises, case incidences and video cases, and an integrative part-ending case (Robbins, 1998).

College instructors face an ongoing challenge to find effective methods of teaching course topics to students. Textbooks lay the foundation for the concepts and theories pertaining to a particular subject, but it is the responsibility of the instructor to effectively convey these ideas to the students. Many textbooks offer case studies and real world examples. While these can communicate messages, they lack true meaning and can seem somewhat artificial to the student (Hunt, 2001).

Effective use of media can enhance a student's learning experience (Serva \& Fuller, 2004). There are multiple types and variations of media that can be used in an OB course. These media can be incorporated into lectures during class time or assigned to view at home. Short situational vignettes can be viewed to describe a particular setting or state of affairs. Television programs, or scenes and clips from movies are often short enough to allow viewing during class. Complete films used to teach OB concepts may be split over several class sessions or assigned to watch as part of a project or homework assignment. Classes that meet once per week are usually long enough in duration to view an entire movie during one class meeting; however, this may limit time available for class discussion on the specific OB topics addressed in the film.

Several individual pieces of media will be discussed in detail in this article. They are all media that the researcher has used to convey $\mathrm{OB}$ concepts while instructing an OB course. In particular, the television programs The Sopranos and The Office, and the films For Love of the Game, 300, and 12 Angry Men, which all offer several OB concepts, will be discussed. 


\section{LITERATURE REVIEW}

The use of media in teaching has dated back to as early as the 1940's. Mayer (1948) examined the relationship between film and sociology. Since then, a great deal of attention has been give to the use of film to instruct sociology courses. Maynard $(1969,1971,1977)$, a strong advocate of classroom media, believes it can help prevent students from getting bored in the sociology classroom setting. During the 1970's, the use of media in the classroom and the literature concerning it began to branch out into other areas of study (Champoux, 1999). Research has bee conducted on the use of media in a wide array of subjects, including humanities (Jurkiewicz, 1990), political science (Kranzdorf, 1980), and anthropology (Ruby, 1976).

Champoux (1999) was among the first to deeply research the use of media as a supplement to instruct OB concepts. His article, Film as a Teaching Resource, explores in great detail various films that can be used to teach OB. While the basis of this article is focused on film in OB and other management courses, there is a great deal of information that can be useful for instructors in any academic discipline. The article provides an overall analysis of the advantages and disadvantages of using film to teach, as well as a comprehensive discussion on copyright issues. It also examines the different functions film serves such as case analysis, experiential exercise, metaphor, satire, symbolism, meaning, experience and time.

Champoux's article also explores the various ways film can be utilized in the classroom. A film can be shown before discussion, which can help students recall what they have already seen once the concept is presented to them in class. Film can be shown after a concept is taught so students are able to apply what they have already learned. Repeating scenes helps in both fashions where students can view a scene to develop a basis, then once again after a concept is discussed to allow them to apply and understand the concepts.

The use of certain media in a classroom can keep students' attention and prevent them from becoming bored during class (Maynard, 1971). Media that could be considered entertainment, such as television programs or movies, contain the additional benefit of adding excitement or humor to the classroom, which could help add to a student's positive learning experience. This type of media can also help alleviate any communication problems caused by differences of age between the instructors and students (Hunt, 2001). Gioia and Brass (1986) noted that college students' learning styles in the traditional classroom have changed from verbal to more visual. Proserpio and Gioia (2007) argue that effective learning occurs when students' learning styles align with in-class teaching styles. This research will build upon the conceptual framework that is found in these studies, using particular pieces of media. Students' perception of effective use of media can help lead to active, effective learning.

Although most of the research on using films to teach has been conducted within the disciplines of social science, there has been attention given to use of movies to teach OB and management courses since the 1990's. Johnson and Iacobucci (1995) examined group communication in the film The Dream Team. Foreman and Thatchenkery (1996) found organizational change concepts in the film Rising Sun.

Clemens (1999) finds many relationships between classic films and management lessons. While the focus is on management, there are several films that are directly related to OB. Clemens finds several OB concepts, such as creativity, in the film Apollo 13. He states that Hoosiers conveys several OB topics related teamwork. Clemens also discusses Socratic leadership in the film 12 Angry Men. Finally, he relates the film Twelve O'Clock High to the problems encountered when turning a troubled organization around.

A great deal of the research in this area can be credited to Champoux. He has published a series of books entitled Our Feature Presentation which encompasses several disciplines of management such as OB (2005), Human Resource Management (2007), Strategy (2005), and Management (2003). Each of these books details approximately 20 scenes from popular films and the management concept that is portrayed during the scene. A brief description of each scene is listed, along with several discussion question intended to exercise the minds of students.

With the majority of research focusing on use of films in OB courses, there has been little research on using television programs to teach OB concepts. Hunt (2001) encourages the use of television programs in OB courses. In the article, Must See TV: The Timelessness of Television as a Teaching Tool, Hunt is able to link many OB 
concepts to popular television programs. He points out the Needs Theories of Motivation in Seinfeld; Perceptual Biases and Errors can be taught using The X Files; Equity Theory is visible in Home Improvement and The Brady Bunch; Lois and Clark: The New Adventures of Superman demonstrates the Job Characteristics Model. Hunt also names popular television programs such as ER, Murphy Brown, Frasier, Roseanne, Friends, Star Trek: Voyager, NewsRadio, and The Flintstones as being television shows which can be used to convey OB concepts.

\section{For Love of The Game}

One popular film that demonstrates OB concepts is For Love of the Game written by Michael Shaara and Dana Stevens and directed by Sam Raimi. The film stars Kevin Costner as Billy Chapel, a 20 year veteran baseball player, who is possibly going to pitch the final game of his long career. Champoux (2005) associated the particular scene entitled Just Throw with several motivational concepts that are often taught in OB courses. Robbins (2008) defines motivation as "the processes that account for an individual's intensity, direction, and persistence, of effort toward attaining a goal" (p. 69). Depending on the selected text for a given OB course, as well as the instructor's customization of the course content, there are numerous theories concerning motivation that may be discussed during the course. Several common theories may be viewed and correlated to this scene.

The scene takes place during the latter part of a baseball game, when catcher and Chapel's friend, Gus Sinski, played by John C. Reilly, walks to the pitcher's mound to talk with Chapel. Chapel has just realized that he is in the midst of pitching a perfect game, which is the top performance any one pitcher can achieve in one game. At this point in the film, the motivational needs of Billy Chapel become visible. He is highly motivated to pitch a perfect game for several reasons. First, he is highly competitive and therefore wants to win the game. Second, he desires to prove to others, and himself, that even at what may be the end of his career, he is still a winning pitcher.

This scene can be associated with several motivation theories in OB. Maslow's Hierarchy of Needs Theory is one of the Early Theories of Motivation (Robbins \& Judge, 2008). Maslow's theory states that individuals are driven by five needs: physiological, safety, social, esteem, and self-actualization. At this point in the movie, Sinski encourages Chapel to continue to pitch as best as he can. He tells him

You just throw whatever you got, whatever's left. The boys are all here for you. We'll back you up. We'll be there. 'Cause Billy, we don't stink right now. We're the best team in baseball right now, right this minute 'cause of you. You're the reason. We're not gonna screw that up. We're gonna be awesome for you right now. Just throw. (Raimi, 1999)

As Chapel nods in acceptance of Sinski's pep talk, his needs begin to change. He was previously pitching to satisfy the esteem need of Maslow's theory, as any pitcher would. Now that Chapel realizes he is nearing the end of a perfect game, his motivation drives him to the next level on Maslow's hierarchy, which is self-actualization. Self actualization is defined as "the drive to become what one is capable of becoming; includes growth, achieving one's potential, and self-fulfillment" (Robbins, 2008, p. 70). Chapel is trying to achieve his overall potential by pitching a perfect game. Sinski's speech motivates Chapel to reach this goal.

One of the more popular Contemporary Theories of Motivation is McClelland's Theory of Needs, developed by David McClelland (Robbins \& Judge, 2008). McClelland's theory suggests that individuals are motivated by three general needs: achievement, power, and affiliation. Throughout the film For Love of the Game, Chapel is portrayed striving to fulfill his need for achievement by increasing his performance as a baseball player. This character also demonstrates fulfillment of his affiliation needs by interacting with his friends and his girlfriend, played by Kelly Preston.

The need for achievement becomes evident in the scene Just Throw. Chapel is possibly playing the final game of his professional career. His team is not going to make the playoffs and the owners are planning to sell the team at the end of the season. Chapel's achievement needs become clear in this scene as he is motivated by Sinski's talk and by the possibility of being rewarded intrinsically. 
This scene demonstrates several other OB concepts. When Chapel sees that team manager Frank Perry, played by J. K. Simmons, has made the decision to warm up relief pitchers in the bullpen, Chapel is motivated because he does not want someone else finishing the job he began. He wants to be identified as the sole person to perform this task of pitching. By rotating jobs and having a relief pitcher finishing the game for him, he will still have performed well, but he will not be credited with an identifiable task, such as a complete game, shutout, nohitter, or perfect game.

Sinski's talk also conveys the message of teamwork and communication. He makes Chapel understand that the team is comprised of a pitcher, catcher, and seven other players in the field. He emphasizes "Just throw." If the batter hits the ball, the team will make the plays so Chapel can achieve his perfect game. When the first batter of the eighth inning hits a ball deep to right field, Mickey Hart, an otherwise sub-par fielder, makes a play by jumping over the outfield wall and catching the ball. If he did not do this, the ball would have been a home run. Chapel would not only have lost his perfect game, but he would have lost a shutout and his team would have lost their lead of 1-0. The next batter hits a hard ground ball between first and second base. The second baseman, Marcus Random, makes a diving play to catch the ball and throw the runner out at first base, still preserving Chapel's perfect game. The final out of the inning is made by catcher Sinski, catching a fairly difficult pop up in foul territory. The scene concludes with the baseball commentator, Vin Scully, making the statement "Billy Chapel is certainly getting more than a little help from his friends." This scene emanates the feeling that this would have been a typical home run on a routine day, but the synergy that has been achieved through teamwork increased the motivation of each individual player.

There are also several other OB concepts visible throughout the film in various scenes. In the scene Hurting, the motivation applications of job rotation and task identity become visible. The scene takes place during the seventh inning of the game, when Chapel has already pitched a fairly long game to this point. He realizes his arm is in a great deal of pain from pitching and doubts himself that he can continue to pitch. He is visited at the mound by Sinski and Perry, who can see that he is in pain. This is when his motivation needs become apparent. Chapel displays the three main components of motivation: intensity, direction, and persistence. His esteem need is very low and he has little confidence that he can physically endure the pain he is feeling, but he is determined to stay in the game. He convinces the somewhat reluctant Perry to allow this.

During the scene Bad News, the current owner, Gary Wheeler, played by Brian Cox, delivers the news to Chapel that the team has officially been sold and the new owners were planning to trade him to another team. The subjects that are discussed, such as the reasons for the team being sold and the possible options for everyone involved can be directly applied to OB. Several OB concepts at the organizational level, such as organizational structure and culture can be observed while watching this scene. In particular, organizational change subtopics are visible in this scene and can be discussed using the suggested questions in Table 1.

Table 1 Suggested Discussion Questions: Organizational Change Subtopics in For Love of The Game

\begin{tabular}{|l|l|}
\hline \multicolumn{1}{|c|}{ Organizational Change Subtopic } & \multicolumn{1}{c|}{ Suggested Questions } \\
\hline Forces of Change & Why are the owners selling the team? \\
\cline { 2 - 2 } & Why is the team moving? \\
\cline { 2 - 2 } & Are external factors forcing the organization to undergo these changes? \\
\hline \multirow{2}{*}{ Change Agents } & Who is making the decision to move the team? \\
\cline { 2 - 2 } & Who is making the decision to trade Chapel? \\
\hline Resistance to Change & Is this a good move for the team? Why or why not? \\
\cline { 2 - 2 } & $\begin{array}{l}\text { How are the other individuals such as other players, coaches, and employees } \\
\text { affected by this organizational change? }\end{array}$ \\
\cline { 2 - 2 } & Will they resist? If so, How? \\
\hline Overcoming Resistance to Change & What can the new owners do to deal with the resistance to change? \\
\hline
\end{tabular}

Instructors can use For Love of the Game to convey these OB topics to their class. The film can be watched during class, however, it is relatively long at 137 minutes. If the class meets once per week for approximately three hours, the film can be viewed during one class session and still have ample time to discuss the specific topics. For courses with shorter class sessions, the viewing will have to take two or more sessions. It is also 
important to note that there are many parts of the film that are not directly involved with OB. OB instructors may choose to either assign this as a homework assignment for students to watch on their own. They can then either write a paper on the OB topics they observed or participate in class discussions on the topic. Instructors may also choose to select particular scenes, such as the three mentioned above, to convey the messages. This can be useful providing the instructor is well prepared and can easily navigate through the film to certain scenes, pausing when necessary. The scene Bad News runs 2 minutes 11 seconds, Hurting runs 1 minute 46 seconds, and Just Throw runs 7 minutes 20 seconds. These three scenes account for 11 minutes 17 seconds in total, and they encompass OB concepts at the individual, group, and organizational level. This leaves a substantial amount of time for class discussions and questions.

A second film that portrays OB concepts is 300 , written by Zack Snyder, Kurt Johnstad, and Michael Gordon and directed by Zack Snyder. The film setting is ancient Greece in 480 B.C. and tells the story of a war between the Spartans and the Persians. King Leonidas, played by Gerard Butler, leads a group of 300 Spartan soldiers against a countless number of Persian soldiers. Although several individual behaviors are visible in the film including motivation, personality, and emotions and moods, group behaviors including teamwork, leadership, power, and politics are more notable. Because this film is relatively new, having been released in 2007, there has been no previous research on its use as a tool for instructing OB.

Perhaps the most evident concept in 300 is the leadership of King Leonidas. In multiple scenes throughout the film, his unrelenting strength and influence is apparent. The opening scene, Spartan Education, can be analyzed for evidence to answer the question of whether leaders are born or trained. As a young boy, Leonidas endured a rigorous training program designed to prepare him for his future role as king. In another early scene, Sparta's Reply, Leonidas is meeting with a messenger sent from Persia along with a group of Persian followers. Infuriated, he draws his sword on the messenger. Immediately, each of his Spartan followers draws a sword on one of the Persian followers. This action demonstrates how Leonidas' followers are trained to do as he does. At the moment that Leonidas becomes violent and kicks the Persian messenger into a ditch, his Spartan followers begin to fight against the Persians. It is clear that the Spartan's actions are highly influenced by their leader.

Leonidas possesses several qualities that make him a charismatic leader. He consistently gives his followers motivational speeches in order to inspire them and stimulate their desire to fight harder and more effectively. In the scene, Hot Gates Battle, the Spartans prepare for their first battle against the mighty Persians. Leonidas preaches loudly and confidently, "This is where we hold them! This is where we fight! This is where they die! Remember this day men, for it will be yours for all time!" In the scene, Today No Spartan Dies, Leonidas declares, "Today no Spartan dies!" In a later battle scene, Prepare for Glory, Leonidas again demonstrates that he is a charismatic leader when he shouts to his men, "No retreat, no surrender! That is Spartan law and by Spartan law we will stand and fight and die! A new age has begun; an age of freedom and all will know that 300 Spartans gave their last breath to defend it!" Leonidas demonstrates the four key characteristics of charismatic leaders.

According to Robbins and Judge (2008), the 4 key characteristics of charismatic leaders are: vision and articulation, personal risk, sensitivity to follower needs, and unconventional behavior. Leonidas exhibits each of these behaviors throughout the film. He maintains a vision of what he believes in and is fighting for. He wants Sparta to be free and he consistently inspires his followers when he conveys this message to them. Leonidas takes personal risks as he is always on the front line of battle, fighting side by side with his fellow Spartans. He is sensitive to his follower needs as evidenced by his decision to only recruit men for his army who have a son to carry on their name if they should die. Finally, Leonidas displays unconventional behavior when he attacks the Persian messenger. Because the Persian is only a messenger, no one would ever expect the king to attack him.

Several scenes in 300 vividly portray the group behavior concept of teamwork. In the scene Ephialtes' Request, Ephialtes, a deformed and exiled Spartan, asks Leonidas to allow him to fight in his army. Leonidas explains that Spartans fight as a phalanx, with each soldier protecting the soldier to the left of him, from thigh to neck, in order to create a single impenetrable unit. He describes how this is the source of the Spartans' strength. According to Robbins and Judge (2008), a work team generates a positive synergy through coordinated effort. This 
impenetrable unit described by Leonidas is visibile in the in the scene titled Hot Gates Battle, and demonstrates the concept of coordinated effort. This synergy created by the phalanx would not be possible if each man acted independently of each other.

The OB group concept of power and politics is evident in 300. In the scene Betrayer's Bargain, Xerxes, leader of the Persians, utilizes his power over Ephialtes. He offers wealth and women in exchange for Ephialtes agreement to act as a spy against his own Spartans. Ephialtes ultimately leads the Persians to the Spartans. In the scene titled Queens Betrayal, the concept of politics that is found in many groups is evident when Therod uses his power and political position in the Spartan council to convince Queen Gorgo, Leonidas' wife, to sleep with him. The queen's main concern is to persuade the council to help her husband, Leonidas.

300 can be a valuable tool for instructors to use to teach group behavior concepts. The film runs a total of 116 minutes, and therefore could be viewed in one session for a class that meets for at least 2 hours at a time. Instructors may choose, however, to select particular scenes to show the class. Selection of particular scenes is ideal for classroom viewing due to nudity and frequent violence in the film.

\section{Angry Men}

A third film that can be used to instruct OB concepts is 12 Angry Men, written by Reginald Rose and directed by Sidney Lumet in 1957. The setting of this film is a jury deliberation room, where 12 jurors must decide the verdict of a murder trial. There has been a great deal of research concerning the use of this film as an instructional tool. This may be due to the fact that this film is much older than the previously discussed films. 12 Angry Men can be used to instruct the topics of interpersonal communication and group dynamics (Proctor, 1991; Proctor \& Adler, 1991), social psychology (Fried, 1998), and various behavioral, organizational, and management situations (Alvarez, Miller, Levy, \& Svejenova, 2004).

12 Angry Men lends itself to using various methods to demonstrate these concepts due to the many film techniques used in the movie. The close up shots used in the film detail the emotions of each juror during the decision making process (Champoux, 1999). The conflict process and conflict reduction can be more easily comprehended through analysis of scenes in the film than through use of a textbook or classroom discussion (Champoux, 1999). In addition to the visual aspects of this movie, the dialogue in 12 Angry Men may be used to exhibit communication processes and concepts (McCambridge, 2003). The use of film as an instructional tool has the potential to move beyond these contexts into the theoretical context (Buchanan \& Huczynski, 2004). 12 Angry Men can portray character development, plot development, and plot twists (Champoux, 2004).

Although 12 Angry Men does not portray OB concepts at the organizational level, it does contain many individual level and, in particular, group level concepts. At the individual level, the unique personality of each juror plays a role in the development of the film and the final outcome. Each member of the jury is an adult male; 11 are Caucasian Americans, the 12th is a Caucasian man who appears to be from a foreign country. Although they share some common characteristics, their different personalities add to the dynamics of the group. One juror is extremely angry and aggressive, while another is introverted and seems he would rather not speak. A third juror makes jokes at every available opportunity.

The emotions and moods that are displayed are also clearly visible and important to the film. Each juror is in a somewhat bad mood due to the heat and lack of air conditioning in the room. This adds to the conflict that they encounter. At various moments in the film, a juror seems to emote their feelings when someone says something they do not agree with.

The concept of individual perception is also visible in this film. The person on trial is an 18 year old young man who is charged with murdering his father. One juror had a previous fight with his own 22 year old son and is not on speaking terms with him. Therefore, he perceives this 18 year old as guilty of murdering his father. This seems to be more important to him than the facts of the case. Another elderly juror believes that the testimony of one witness for the prosecution, an elderly man, may not be completely accurate. He believes that because the witness is elderly he may be lonely and merely serving as a witness for the attention. The shortcuts of selective 
perception, the halo effect, contrast effect, projection, and stereotyping can all be observed throughout the film, as the jurors try to give explanations of why they think the young man is guilty.

The rational decision making process can also be observed in detail in 12 Angry Men. At the beginning of the film, 11 jurors believe the boy is guilty and are ready to give the verdict. The only outcast, Juror \#8, played by Henry Fonda, uses the rational decision making process to come to his decision of not guilty.

According to Robbins and Judge (2008), the first step in the rational decision making process is to define the problem. A decision must be made of whether a young man is innocent or guilty and Juror \#8 was not there to witness it himself. The second step is to identify decision criteria. Juror \#8 could vote not guilty and examine the facts further or vote guilty and the young man would receive the death penalty. The next step is to allocate weights to the criteria. If Juror \#8 votes guilty, the young man will die without having much of an opportunity for a defense. If he votes not guilty, there will at least be an opportunity for more information to be revealed. He feels that the future of an 18 year old young man's life should not be decided in a mere five minutes. The fourth step is to develop alternatives. Juror \#8 develops several alternatives pertaining to the boy's innocence. He believes it is possible he did not remember the details of the movie he claims to have seen because he was under emotional stress. He believes the witnesses may have been incorrect in their testimonies. The fifth step is to evaluate the alternatives. He brings each alternative possibility to the table of jurors. The group begins to be persuaded to believe in them. The sixth and final step is to select the alternative. He believes there is a chance the young man is not guilty and tries to convince the others.

Several behavioral concepts are portrayed throughout the film that center on group behavior and group decision making. The question of whether individual decision making or group decision making is more effective can be examined through use of 12 Angry Men. While each has its own advantages in certain situations, this film shows the advantages of group decision making. Robbins and Judge state that group decision making generates more complete information and knowledge (2008). While the defense attorney did not notice certain aspects of the case, such as the eyeglass marks on the witness' nose, the fact that the elderly witness could not have limped to witness the crime in the amount of time he stated, or the fact that the stab would not have been slanted downward, or the sounds of the train passing, the 12 jurors together noticed them as a group.

Other group behavioral concepts are also visible in 12 Angry Men. The concept of conformity is evident in the opening scenes. When the jurors take a preliminary vote by raising their hands if they think the young man is guilty, some jurors raise their hands immediately, while several wait and look around the table. When they see that the majority is voting guilty, they conform and vote with them. The concept of groupthink immediately follows. Since the majority of the group begins by voting guilty, many are persuaded to follow because of the overwhelming evidence that is presented by the majority. It is interesting to watch Juror \#8 resist the pressures of conformity and groupthink as he refuses to change his vote based on what the majority of the group believes.

12 Angry Men is a useful film to convey group and individual behavior concepts. The entire film runs for 96 minutes which, depending on the duration of a class, can usually be shown in one or two sessions. There is no violence, nudity, or profanity in the film.

\section{The Sopranos}

The Home Box Office (HBO) series The Sopranos, created by David Chase, offers several different scenarios that can be applied to OB concepts, as well as many other business management disciplines. Although the program depicts a New Jersey mafia family's professional and personal lives, there are numerous demonstrations of management and OB concepts within the episodes that can be used to instruct students. In her book, Leadership Sopranos Style: How to Become a More Effective Boss, Himsel (2004) provides a variety of examples of how emerging leaders can learn leadership theories from the show's main character, Tony Soprano. Episodes are discussed with visual portrayals of leadership theories, as well as other specific OB concepts.

According to Himsel, charismatic leadership can be observed in the episodes From Where to Eternity and D-Girl. The episodes Meadowlands, I Dream of Jeanne Cusamano, Pie-O-My, and The Happy Wanderer all 
illustrate solid examples of how an effective leader should receive feedback from their employees. Communication methods can be studied in the episodes Pilot, 46 Long, and Mr. Ruggerio's Neighborhood.

One particular episode of The Sopranos, All Due Respect, makes many references to OB concepts, in particular leadership and power. This episode is the thirteenth and final episode of Season five. Tony Soprano is the leader of a New Jersey organized crime family. His character is portrayed as a very powerful leader who commands respect from his followers. Throughout this episode, multiple leadership theories can be applied to Tony's behavior. Leadership is defined as the ability to influence others toward the achievement of a vision or a set of goals (Robbins \& Judge, 2008). Tony's leadership and use of power can be observed repeatedly throughout this episode.

The main plot of this episode deals with the battle between the Soprano crime family and a rival New York crime family. The conflict between the two families started because Tony's cousin, Tony B., played by Steve Buscemi, killed the brother of a New York boss. The New York family is seeking revenge on Tony's crew. Despite Tony's belief that his cousin was wrong, he chooses not to turn Tony B. over to the New York family.

The second scene of All Due Respect, titled Dissention in the Ranks, depicts a birthday party for Raymond, a member of Tony's crew, where most of the crime family is present. The scene opens with the men mingling around a dinner table. Sylvio, Tony's consigliere or advisor, hangs up his phone and announces to group that Tony is held up and is going to be late and they should start without him. Although Raymond is the guest of honor, Tony is still the main influence, even during his absence. The group begins to discuss the situation with the New York family. They feel that a member of the New York family will retaliate by killing a member of their family. A competitive conversation breaks out where each member makes his case about why he should be the one that is killed. Each man believes that he is closest to Tony and, therefore, will be the one on which New York will seek revenge. This is a true display of power as each follower is boasting to be closest to Tony and the reward for this feat is death. This all occurs despite the absence of their leader, Tony.

Tony then enters the room and each group member immediately motions to stand up, including the guest of honor, before Tony tells them to remain seated. He then gives a speech to the group, in which several OB concepts could be applied. Tony demonstrates charisma during this speech. He is confident, his words are very powerful, and he commands the attention of the others. While he is speaking, the room is completely silent and Tony has everyone's full attention. He informs the group that he will not turn Tony B. over to the New York family, even though his cousin's actions were inappropriate. Tony will address this matter in his own way. He reassures his followers that he would offer the same protection to any one of them because they are a family and they will deal with this "as a family".

In the next scene, Problem with Authority, a spirited conversation takes place between Tony and Sylvio. Sylvio has always been Tony's most loyal follower and his voice of reason in many situations. Sylvio informs Tony that many of his followers would do whatever he ordered, but they are unhappy with the decision to protect Tony B. from the New York family. Again, Tony displays his power by not backing down to Sylvio and standing his ground as leader. He tells Sylvio that he has his reasons for making his decisions and he will deal with the situation in time.

In the scene Goodbye Guilt, Tony is involved in another spirited conversation with Paulie, another loyal follower. Tony arrives at Paulie's home to talk about the situation. He notices Paulie has a painting of him hanging on the wall. In the painting Tony is standing next to his former racing horse and is dressed like a general. This demonstrates Tony's power and influence on others. Paulie, a strong-minded criminal unlikely to bow down, has such tremendous respect for Tony, his leader, that he has a painting of him in his home. Tony clearly reminds him of a general.

Later in this scene, Tony makes the decision to handle the situation with his cousin. He finds Tony B. and kills him, quickly. Tony's rationale behind this decision is that Tony B. had to be killed for what he did, but he would not allow the New York family to do it. Allowing them to handle it would mean his cousin would be tortured before dying. Tony did not want this fate for Tony B. as he is part of both his crime and personal family. Another 
reason for this decision was that by allowing the New York family to kill his cousin, Tony would be giving up power to them by letting them have their way.

The described scenes as well as the entire episode demonstrate that Tony's behavior can be associated with some behavioral theories of leadership. The Ohio State Studies found that leadership is comprised of two dimensions: initiating structure, which deals with defining and structuring roles to achieve goal attainment; and consideration, which deals with job relationships, mutual trust, respect, and regard for followers' feelings (Robbins \& Judge, 2008). Tony has structured his work and his decisions around what he feels is right and how he chooses to handle the situation. He is also taking Tony B. and other members of his crime family into consideration. The University of Michigan Studies found that leadership is comprised of two dimensions: employee oriented leaders, emphasized taking an interest in the needs of followers; and production-oriented leaders, emphasized the technical aspects of the job (Robbins \& Judge, 2008). Again, Tony displays both these behaviors by taking what he believed were his followers' best interests into account. He cared about what happened to Tony B. and the other members of his family. He is also focused on production because he has business relationships with the New York family and he is concerned about the family losing business.

Tony exhibits charisma throughout All Due Respect. He displays each of the key characteristics of charismatic leadership in this episode. He has a vision of what he desires to happen and, more importantly, what he does not want to happen. Tony tells his followers that he is not going to give his cousin up. He conveys the importance of this to them and explains the reason for making this decision. Tony takes a personal risk in several ways. He puts himself in danger because, by his decision not to give his cousin up, he is taking on the personal risk of having the New York family kill him. With his decision to kill Tony B. himself, he takes on the personal risk of possibly getting killed himself. Tony shows sensitivity to his followers' needs by not offering Tony B. to the New York family. He also tells his followers that he would offer the same protection to any of them. He shows unconventional behavior by killing his own cousin himself, when his followers believed he was going to let his cousin get away with no repercussions. The respect the followers have for Tony is evident in the scene titled Forgiven. They realize Tony has made a good decision by killing Tony B. and they show their appreciation by having breakfast waiting for him and telling him that they would do it "anytime boss". Sylvio gives Tony an approving pat on the shoulder.

At the group level of analysis, the following OB concepts are also visible. Group decision making is an important concept that can be observed. Individually, Tony makes his decision about Tony B. The group decision would have been different. Non-verbal communication is displayed during the scene Problem with Authority. After Sylvio and Tony discuss business, Sylvio asks Tony if he needs him for anything else. Tony says nothing; he only sits with his feet up and blows cigar smoke. Even though no words were spoken, Sylvio received the message that Tony did not want him there any longer.

Several OB concepts at the organizational level can also be applied. The crime family can be compared to an organization, with Tony as the leader. The structure, design, and culture can all be discussed. The fact that the New York family is the competition, but they actually can work together on business deals can also be discussed.

The entire episode of All Due Respect runs for a total of 53 minutes and should be able to be viewed during one single class session. Instructors may choose to show clips of the episode, or particular scenes instead because there are several scenes that, while relevant to the storyline, do not pertain directly to OB. It should also be noted that there are some strong scenes in this episode containing nudity, violence, and strong language. If an instructor is familiar with the episode, the nudity and violence can be avoided by fast forwarded or skipping scenes. The strong language, however, is a near constant throughout the episode and would be difficult to avoid without losing a good deal of OB content.

\section{The Office}

The setting of the popular NBC situation comedy The Office is the Scranton, Pennsylvania branch office of a paper supply company. Because the show takes place in an actual work environment, it provides a more real life representation of the workplace for instructing various business related topics. Although The Office is a satirical 
comedy, it portrays the typical everyday behavior of the American workplace, including common personal and professional problems, employee behavior, and management practices. This more realistic visual aide allows students to relate the common office-place interplay they observe to their own, possibly similar, situations in their own work environment (DelCampo, Boudwin, \& Hines, 2007).

There has not been a great deal of literature concerning the use of The Office as an instruction tool. The reason for this may be because the show is relatively new, with its first season airing in 2005. In their book, That's What She Said, DelCampo, Boudwin, and Hines (2007) discuss each episode of the first two seasons. This book, intended to be used in a management classroom, includes a brief summary of each episode, relevant topics in each episode, clip descriptions that describe the specific scenes suggested for class viewing, and discussion questions with possible answers. According to the authors, The Office could be used as an instructional tool to teach courses in Organizational Behavior, Human Resource Management, and many other management courses.

One episode that can be used when instructing OB concepts is Did I Stutter? from Season 4, which aired for the first time in May, 2008. As is the case with many episodes of The Office, Did I Stutter? provides multiple scenes in which OB concepts can be observed. At the individual level of analysis, not only are the various personalities of each employee evident, but their individual characteristics are accentuated during the interactions between them. One employee named Dwight demonstrates a proactive personality. This is contrasted to another employee, Andy, who has an extraverted personality, while they are negotiating the sale of Andy's car. Each personality stands out as it becomes clear that Dwight has a much stronger personality and is more successful in the negotiation. These personalities, along with those of the other characters can be examined using the Myers-Briggs Type Indicator, the Big 5 Model, or the Personality-Job Fit Hexagon (Robbins \& Judge, 2008). A second individual level concept evident in this episode is motivation and McClelland's Theory of Needs. While viewing this episode, students can analyze which need drives each of the characters. Michael, the regional manager of the Scranton branch, is driven by the need for affiliation, while Dwight is driven by the need for power. Toby and Stanley appear to be driven by the need for achievement.

Several group level concepts are also visible in this episode. The concept of group decision making is present throughout the episode. In the opening scene, Michael is looking for "fun" ideas concerning the wet cement outside. Although silly and humorous, there are many important lessons to be learned. While individually, Michael cannot come up with a good idea for the cement, as a group the characters are able to increase their creativity and come up with an idea. Several characters offered ideas that were not acceptable, until Kelly suggests Michael put handprints in the cement. Jim then builds on that idea by suggesting that Michael put his face in the cement. This demonstrates the advantages of group decision making as opposed to individual decision making. This scene also shows teamwork and the synergy that is created by a team working together. Kevin begins by suggesting Michael write his initials; Andy takes this idea and transcends this by suggesting Michael draw a picture; Kelly gets even more creative with her idea of handprints; Pam "translates" Kelly's suggestion so everyone can understand; Jim builds on that idea to make it even better; and Michael, ultimately puts his face in the cement to make a print. None of the characters would have thought of this idea on their own, but together a synergy was formed and each built upon the others.

The next scene is a brainstorming session among the entire office staff. Michael calls this meeting to develop new ideas for energizing the office. Brainstorming is a group decision making technique to generate new ideas. The group decides on an idea to rerecord the office's outgoing message to energize the company. This scene also provides an example of deviant workplace behavior through Stanley, one of the paper salesmen. When Michael asks him a question, he is blatantly insubordinate. This illustrates that not every employee is group-oriented and may work better individually, depending on their individual personality.

The episode contains one scene that portrays the power and politics that may be present in the workplace. Ryan, Michael's boss from the corporate offices, asks Jim, a salesman, into the conference room and issues him a formal warning about his job performance, with Toby, the Human Resources representative present. In a previous episode, Jim had made comments to Mr. Wallace, Ryan's boss, that the website Ryan developed was not very effective for the organization. Jim feels that Ryan is retaliating against Jim for these actions by using his power to 
give him a formal warning. By watching this single episode, it is evident that there are many other actions that are much more deserving of a formal warning than anything Jim has ever done.

Did I Stutter? contains one scene that portrays conflict between Michael and Stanley and the five stages of conflict can be observed in this scene. The first stage, potential opposition, is present as Michael and Stanley have very different personalities. The second stage, cognition and personalization, occurs when Michael asks Stanley a question and Stanley is openly subordinate. Both parties become aware of the conflict during this stage. The third stage, intentions, can be observed, when Michael decides he will confront Stanley and "fake fire" him. The next stage is behavior. In this stage, the conflict becomes visible as Michael pretends to fire Stanley and Stanley responds by yelling at him and insulting him. Michael then asks everyone to leave the room. The fifth and final stage, outcomes, occurs when Michael questions Stanley about his attitude. Stanley calmly tells Michael that he does not respect him because of his actions. Michael accepts this, but reinforces that Stanley cannot speak to him that way in the office because Michael is the boss.

Michael's leadership style can be critiqued throughout this episode. His characteristics can be analyzed according to the Ohio State studies, where he possesses a great deal of consideration; the University of Michigan studies, where he is extremely employee-oriented; the Fiedler Model, where is high in leader-member relations; or the leader-member exchange theory, where he places Jim and Pam in the in-group and Toby and Dwight in the outgroup.

This episode also contains a scene where organizational structure can be observed. When Michael is unsure of how to handle his situation with Stanley, he asks Dwight for advice. Dwight demonstrates the organization chart with the current chain of command. In this scene, the table of organization and span of control are visible. The various responsibilities of key positions are detailed here. Stanley is Jim's subordinate, but only in sales related matters. Ryan can discipline Stanley, but that would skip Michael in the chain, rendering him powerless. It is clear that this organizational structure is very bureaucratic and mechanistic. This scene also compares two different types of organizational structures. After reviewing the current chain of command with Michael, Dwight displays another organization chart, which he calls "the emergency disaster mode". He shows that, if Michael would put him in charge temporarily, everyone would report to him. This is an example of a simple structure with a much larger span of control and decision making is much more centralized.

The entire episode of Did I Stutter? runs approximately 22 minutes. This is short enough to be viewed during one single class session. To be completely effective, an instructor should prepare prior to displaying this episode to become familiar with certain scenes that depict certain concepts. The scene where Dwight displays and compares the organizational structures runs for approximately 1 minute, with a view of the chart for only a few seconds. An instructor may choose to pause the episode on this still shot so the class may analyze the chart.

Conclusion

Previous literature has discussed the effectiveness that certain media sources may have in a classroom (Champoux, 1999). This article builds upon previous literature that the media sources discussed in this article may be, if used appropriately, effective instructional tools to teach OB concepts. For Love of the Game, 12 Angry Men, 300, The Sopranos, and The Office can all be used as visual aids to convey OB topics at the individual, group, and organizational levels of analysis.

\section{AUTHOR INFORMATION}

Dr. Thomas A. Kernodle received his Ph.D. in Business Administration from Touro University International. He also holds an M.B.A in Business Administration from Regis University and a B.S. from New Jersey City University. He is currently employed by Brooklyn-Queens Healthcare of New York as a hospital director. Dr. Kernodle is also a Core Professor of Business Administration for TUI University and an adjunct professor for Berkeley College in New York City. He currently resides with his family in New Jersey. 


\section{REFERENCES}

1. Alvarez, J. L., Miller, P., Levy, J., \& Svejenova, S. (2004). Journeys to the self: Using movie directors in the classroom. Journal of Management Education, 28(3), 335-355.

2. Buchanan, D., \& Huczynski, A. (2004). Images of influence: 12 Angry Men and Thirteen Days. Journal of Management Inquiry, 13, 324-335.

3. Champoux, J. E. (1999). Film as a teaching resource. Journal of Management Inquiry, 8(2), 206-217.

4. Champoux. J. E. (2003). Our Feature Presentation: Management $\left(1^{\text {st }}\right.$ ed.). Mason, OH: Thomson SouthWestern.

5. Champoux, J. E. (2004). Commentary on Filmmaking and Research and Images of Influence. Journal of Management Inquiry, 13(4), 336-340.

6. Champoux, J. E. (2005). Our Feature Presentation: Organizational Behavior ( $1^{\text {st }}$ ed.). Mason, OH: Thomson South-Western.

7. Champoux. J. E. (2005). Our Feature Presentation: Strategy ( $1^{\text {st }}$ ed.). Mason, OH: Thomson SouthWestern.

8. Champoux, J. E. (2007). Our Feature Presentation: Human Resource Management (1st ed.). Mason, OH: Thomson South-Western.

9. Chase, D. (Writer), \& Patterson, J. (Director). (2004). All due respect [Television series episode]. In B. Grey \& D. Chase (Producers), The sopranos. New York: Brad Grey Television.

10. Clemens, J. K., \& Wolff M. (1999). Movies to Manage By: Lessons in leadership from great films. New York: McGraw-Hill.

11. Daniels, G., (Writer) \& Einhorn, R. (Director). (2008). Did I stutter? [Television series episode]. In S. Carell (Producer), The office. Los Angeles: Reveille Productions.

12. DelCampo, R. G., Boudwin, K. M., \& Hines, S. L. (2007). That's What She Said: A Guide to Using “The Office" to Demonstrate Management Parables, Organizational Behavior and Human Resource Management Topics in the Management Classroom. Albuquerque, NM: DelCampo, Boudwin, \& Hines.

13. Fried, C. B. (1998). Using 12 Angry Men as an integrative review of social psychology. ERIC Clearing House Accession No. ED4200084, 9 pages.

14. Foreman, J., \& Thatchenkery, T. (1996). Filmic representation for organizational analysis: The characterization of a transplant organization in the film Rising Sun. Journal of Organizational Change Management, 9, 44-61.

15. Gioia, D. A. \& Brass, D. J. (1986). Teaching the T.V. generation: The case for observational learning. Organizational Behavior Teaching Review, (10)11-18.

16. Himsel, D. (2004). Leadership Sopranos Style: How to Become a More Effective Boss. Chicago: Dearborn Trade Publishing.

17. Hunt, C. S. (2001). Must see TV: The timelessness of television as a teaching tool. Journal of Management Education, 25(6), 631-647.

18. Johnson, S. D., \& Iacobucci, C. (1995). Teaching small group communication with The Dream Team. Communication Education, 44, 177-182.

19. Jurkiewicz, K. (1990). Using film in the humanities classroom: The case of Metropolis. English Journal, 79, 47-50.

20. Kranzdorf, R. I. (1980). Political science film courses: More than meets the eye. Teaching Political Science, 7, 345-352.

21. Lumet, S. (Director). (1957). 12 angry men [Motion Picture], United States: Orion-Nova Productions.

22. Mayer, J. P. (1948). Sociology of Film: Studies and Documents. London: Faber and Faber.

23. Maynard, R. A. (1969). The social studies and media. Social Studies, 60, 327-329.

24. Maynard, R. A. (1971). The celluloid curriculum: How to use movies in the classroom. New York: Hayden.

25. Maynard, R. A. (1977). Classroom cinema. New York: Teachers College, Columbia University.

26. Proctor, R. F., II. (1991) Teaching group communication with feature films. Paper presented at the $77^{\text {th }}$ Annual Meeting of the Speech Communication Association.

27. Proctor, R. F., II \& Adler, R. B. (1991). Teaching interpersonal communication with feature films. Communication Education, (40)4, 393-400.

28. Propserpio, L. \& Gioia, D. A. (2007). Teaching the virtual generation. Academy of Management Learning \& Education, (6)1, 69-80. 
29. Raimi, S. (Director) (1999). For love of the game [Motion Picture], United States: Universal Pictures.

30. Robbins, S. P. (1998). Organizational Behavior: Concepts, Controversies, and Applications (8th ed.). Upper Saddle River, NJ: Simon and Schuster.

31. Robbins. S. P., \& Judge, T. A. (2008) Essentials of Organizational Behavior ( ${ }^{\text {th }}$ ed.). Upper Saddle River, NJ: Pearson Prentice Hall.

32. Ruby, J. (1976). Anthropology and film: The social implications of regarding film as communication. Quarterly Review of Film Studies, 1, 436-445.

33. Serva, M. A. \& Fuller, M. A. (2004). Aligning what we do and what we measure in business schools: Incorporating active learning and effective media use in the assessment of instruction. Journal of Management Education, (28)1, 19-38.

34. Snyder, Z. (Director). (2006). 300 [Motion Picture], United States: Warner Brothers Pictures. 
NOTES 